\title{
Teaching in Rural Communities of the Po Valley, 1861-1900: An Idea of Agricultural Education Described by Agrarian Bulletins
}

LUCIANO MAFFI AND MARTINO LORENZO FAGNANI

KEYWORDS: nineteenth-century Italy, rural society, history of teaching, natural resources.

JEL CODES: N33, N53, O35, 015.

$I$

talian agricultural modernization in the late $19^{\text {th }}$ century was partly the result of increased environmental and agronomic knowledge acquired from primary school school teachers and vocational institutes contributed to agricultural and environmental education in rural areas of Northern Italy. These practices also raised awareness concerning social and cultural problems in rural areas. Laboratory activities and field trips played a fundamental role in teaching strategies that combined theoretical and practical lessons, putting students in direct contact with the territory and its resources.

In the research presented here, three case studies are analysed. The first is the network of primary schools brought to life by resourceful teachers and the financial support of local authorities in the Monza area. The second focuses on the Practical School of Agriculture in Voghera and its field trips. The third looks at the practical training course for cellarmen that was planned in Stradella. Italian innovation in the final decades of the $19^{\text {th }}$ century gave careful attention to the characteristics of each territory while also looking at highly successful didactic experiences in the most advanced countries. 


\section{Enseñanza en las comunidades rurales del valle del Po, 1861-1900: Una idea de educación agrícola descrita por boletines agrarios}

\section{PALABRAS CLAVE: Italia del siglo XIX, sociedad rural, historia de la enseñanza, recursos naturales.}

\section{CÓdIGOS JEL: N33, N53, 035, 015.}

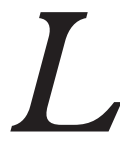
a modernización agrícola italiana, a partir de las últimas décadas del siglo XIX, también fue el resultado de un aumento en el conocimiento ambiental y agronómico desde la escuela primaria. El artículo abre una nueva perspectiva de investigación, analizando la contribución proporcionada por los maestros de primaria y los institutos profesionales de algunos centros rurales del norte de Italia a la educación agrícola y ambiental. Estas prácticas también condujeron a una nueva conciencia de los problemas sociales y culturales de las zonas rurales. Gracias a estas enseñanzas, también prácticas, los estudiantes se pusieron en contacto directo con el territorio y sus recursos. Por lo tanto, las actividades prácticas y los viajes de aprendizaje desempeñaron un papel fundamental en esas estrategias de enseñanza.

Para que su objetivo sea más claro, el artículo propone tres estudios de caso. El primero es la red de escuelas primarias en el área de Monza, animada por maestros ingeniosos y con el apoyo financiero de las autoridades locales. El segundo estudio de caso se centra en la Escuela Práctica de Agricultura de Voghera y sus viajes de aprendizaje. El tercer ejemplo lo da el curso de capacitación práctica para bodegueros planeado en Stradella. La experiencia italiana, que en las últimas décadas del siglo XIX mostró características innovadoras, reveló una atención particular a los territorios y sus diferentes características, al observar también las experiencias didácticas más exitosas llevadas a cabo en los países más avanzados.

Received: 2020-01-25 - Revised: 2020-08-07 • Accepted: 2020-12-12

Luciano Maffi [orcid.org/000-0003-0933-5758] is Lecturer in Economic and Global History at the University of Parma (Italy). Address: Department of Economics and Management, Via fohn Fitzgerald Kennedy - Palazzina "Feroldi", 6 - 43125 Parma (PR). E-mail: luciano.maffi@unipr.it

Martino Lorenzo Fagnani [orcid.org/0000-0003-0604-0479] has obtained his PhD in Modern History at the University of Pavia. Address: Department of Humanities, Piazza del Lino 1 - Palazzo "San Tommaso”-27100 Pavia (Italy).Email: martinolorenzo.fagnani01@universitadipavia.it 


\section{INTRODUCTION}

Today, environmental education and attention to responsible consumption and production are among the focal points of primary and secondary education. In fact, with climate change and the advancement of consumer society, it has proved necessary to raise awareness of these issues from a very young age. In this context, a path that combines theoretical teaching with practical experience and knowledge of the area is fundamental. In Italian primary and secondary schools, the guidelines known as Sustainable Development Goals of Agenda 2030, indicated by the Education for All international movement led by UNESCO, United Nations and partner organizations, have been put into practice by intensifying visits to companies, the use of agricultural gardens, food education and, in general, interaction with the local area ${ }^{1}$.

On the other hand, in recent years environmental history and rural history have considered the repercussions of human activity on the environment, especially in production and in the agricultural sector (Alfani, Di Tullio \& Mocarelli, 2012). The history of agricultural teaching also falls within this field of study, a topic addressed both at primary education level and on that of secondary and professional training, which would then have an impact on the attitude of Italian rural society towards agriculture, resources, and environment. In terms of scientific literature, among the most important Italian historians who have dealt with the professional training of primary school teachers and the spreading of skills through these figures are Giovanni Vigo (Vigo, 1971, 2017; Pagano \& Vigo, 2012), Angelo Bianchi (Bianchi, 2012), Luciano Pazzaglia (Pazzaglia \& Sani, 2001; Pazzaglia, 2002), Omar Mazzotti and Massimo Fornasari (Mazzotti \& Fornasari, 2021). As regards the study of the professional and technical figures in the Italian agri-food sector during the $19^{\text {th }}$ century, Gianpiero Fumi (Fumi, 2016), ManuelVaquero Piñeiro (Vaquero Piñeiro, 2006, 2011, 2014) and Rossano Pazzagli (Pazzagli \& Biagioli, 2004) conducted the main research projects. Finally, a particular sector of investigation is the phenomenon of agricultural and industrial fairs that developed above all in central-northern Italy. It favoured the circulation of updated scientific and technical notions, sometimes acting as a didactic experience for scholastic training courses. In this area we must refer to Sergio Onger (Onger, 2010; Bigatti \& Onger, 2007), Giorgio Bigatti (Bigatti, 2000), Anna Pellegrino (Pellegrino, 2017), Luciano Giacchè (Giacchè, 2012) and some studies coordinated by Sergio Zaninelli (Zaninelli, 1991). Adri-

1. For the Sustainable Development Goals and its reception by the Italian Ministry of Education and the National Institute for Documentation, Innovation and Educational Research, please refer to the following pages of the UNESCO and UN sites: https://en.unesco.org/sdgs, https://www.sdgfund.org, https://unric.org/it/agenda-2030/, https://www.un.org/sustainabledevelopment/, https:// scuola2030.indire.it [links consulted $29^{\text {th }}$ December 2019]. 
ano Prosperi has recently analysed the living conditions of Italian rural society (Prosperi, 2019).

This article is part of this historiographical framework. However, it intends to add a new perspective, analysing the contribution provided to agricultural and environmental education by the teachers of some rural areas in Northern Italy. These figures, flanked by other didactic and educational paths such as visits to industrial and agricultural fairs and the circulation of specialized publications, would lead to a new awareness of the social and cultural problems of rural areas. At the heart of this research, there are the first courses of Italian primary schools, practical schools and training courses which placed students in direct contact with the territory and its resources, obviously considering them in their different educational dimensions, ages, and social backgrounds.

We outline the didactic dynamics in the frame of rural Italy at the end of the $19^{\text {th }}$ century through three case studies from the north of the country. The first is the network of primary schools in the Monza area, animated by enterprising and original teachers and financially supported by the local comizio agrario (agrarian committee). The second is the Royal Practical School of Agriculture of Voghera and the organization of its field trips. The third is the training course for the profession of cellarman in Stradella.

\section{MAPA 1}

Lombardy with Monza, Voghera, Stradella, and the areas of Brianza and Oltrepò Pavese

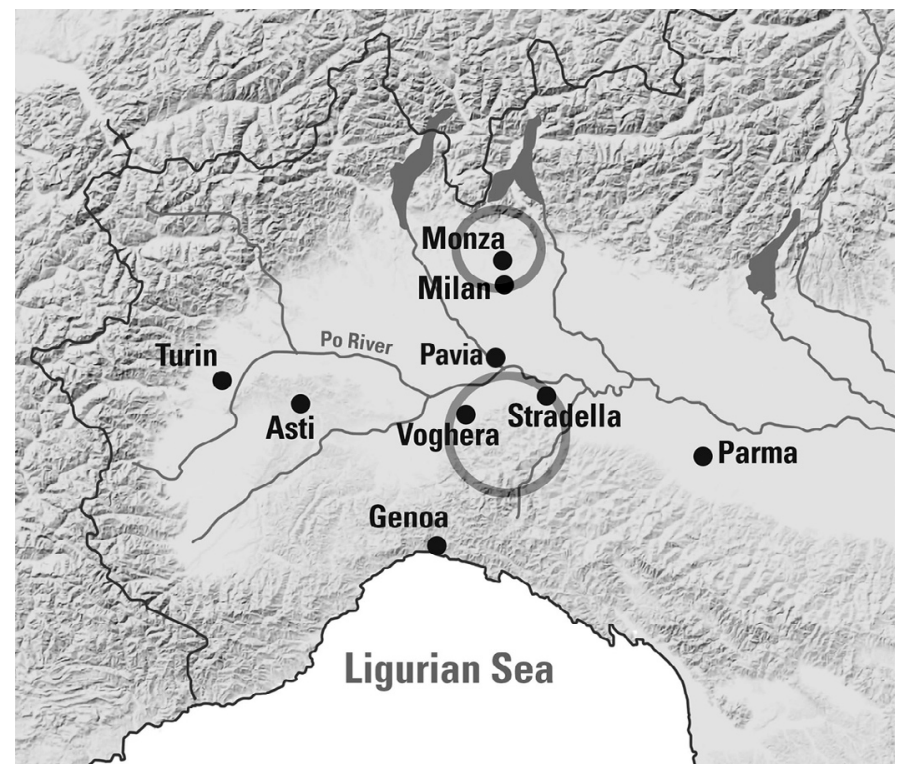


We chose the period from 1861 to 1900 because it was key in the social and economic organization of the new Italy. The Kingdom, established in 1861, came from a centuriesold geopolitical and cultural fragmentation, which was however not yet fully remedied, given that the territorial changes that led to the current conformation of the Italian Republic continued for almost ninety years. Obviously, the educational situation was not homogeneous across the peninsula. The primacy of Italian primary education in the early 1860s belonged to the north, especially Piedmont and Lombardy ${ }^{2}$. Italian practical and professional education was in a more complex situation, fragmented between contemporary and old-fashioned institutes, sometimes aimed at children and teenagers and other times at adults, with varying teaching strategies (Carina, 1871: 65-79).

Nonetheless, if Lombardy and Piedmont were models for post-1861 Italian education, was it also the case for agricultural education, from primary schools to more specialized courses? The final decades of the $19^{\text {th }}$ century were essential for preparing future labourers for the agricultural sector, which would considerably improve in skills and effectiveness in the early $20^{\text {th }}$ century. Thus, our article considers the strengths and critical points of the "Lombard model" applied to the specific field of agricultural education in a particular time of transition. The case studies of Monza, Voghera and Stradella allow us to have three different points of view, both at an educational level and in terms of the agricultural scenario considered in the same region-or compartment, to use the term of the time albeit with different socio-cultural backgrounds. Monza, in fact, had belonged to the Hapsburg Kingdom of Lombardy-Venetia, while Voghera and Stradella had belonged to the Savoyard Kingdom of Sardinia.

In terms of sources, the most important ones to which we refer are the bulletins of the comizi agrari $^{3}$, which sought to reach rural society in a widespread manner, communicating progress and suggestions for improvement in agricultural practices. However, in the second half of the $19^{\text {th }}$ century, the Italian population had very high levels of illiter-

2. In the case of Piedmont, it is still difficult to fully understand the good level of education reached before the 1860s when it was the heart of the former Kingdom of Sardinia: until 1820 the number of teachers fluctuated, later there was a certain increase, from 1850 a good diffusion of popular education throughout Piedmont and in the Alpine region of the Savoy Kingdom was clear, including good public education for girls. In the case of Lombardy, the good education system and the fine training of the primary school teaching staff were due to the support policies both during the previous Kingdom of Lombardy-Venetia dependent on the Hapsburgs of Vienna, and during the Napoleonic period in the early $19^{\text {th }}$ century. In this regard VIGO (2012), and SoldDANI (1981).

3. Our article refers above all to bulletins of comizi agrari and similar institutions, so far little used in the historiographical analysis of the education of rural youth. However, a complementary investigation could include the analysis of the documentation kept in the archives of provinces, municipalities, and chambers of commerce. 
acy, not to mention the innumerable dialects spoken on national soil. So what impact did bulletins have on rural society and what was the profile of the most receptive reader?

\section{INSTITUTIONAL AND SOCIO-ECONOMIC FRAMEWORK}

The Kingdom of Italy was proclaimed on $17^{\text {th }}$ March 1861 and included most of the peninsula. In 1866, the Kingdom annexed the Veneto region with the Mantua area and, with the conquest of Rome in 1870, the territory of the former Papal States. At the end of 1871 , a census was carried out: it revealed that the Italian population was $26,801,154$, with a concentration in the province of Milan (1,009,794 inhabitants), followed by Turin $(972,986)$, Naples $(907,752)$, Rome $(836,704)$ and Genoa $(716,759)^{4}$. Between 1872 and 1878 , the average birth rate of the Kingdom -summing the annual averages- was recorded at 37.16 (per 1,000 population): the highest birth rates were in the provinces of Bari (42.82), Rovigo (41.79) and Foggia (41.74). Average mortality in the same period saw some provinces in the south at the top, such as Campobasso (36.53 deaths per 1,000 inhabitants), Foggia (35.33) and Potenza (35.07), but also a central province with a high malarial rate, Grosseto (35.25) (Zampa, 1881).

In this demographic scenario, in Italy the need for agricultural productivity and knowledge of new technical practices was accompanied by the safeguarding of the territory that fuelled the national economy and therefore had to be preserved. To increase awareness of this matter in a nation with a troubled historical identity, an economy which was not particularly flourishing and a very high illiteracy rate, solid and widespread teaching plans were needed. In 1861 and 1866 the Ministry of Industry, Agriculture and Commerce organized commissions of scholars and politicians to modify the Casati law and insert guiding principles that would enhance the practical nature of teaching. Although these initiatives did not succeed completely, the foundations were laid for the establishment of the first two higher education agricultural institutions, respectively in Milan and Portici, near Naples; from the 1870s many others would be established throughout the Italian territory (Vaquero Piñeiro, 2012).

At the same time, one of the main problems was cultural standardization, which had become essential after the geopolitical unification. From this point of view, it is necessary to consider both the deep cultural diversity that historically characterized the Italian peninsula -for centuries fragmented into different states- and the high rate of illiteracy that characterized the rural areas and the southern regions of the Kingdom. To give an idea of this

4. Regarding the population number, see Il censimento della popolazione... (1871). 
second aspect, consider that in $186175 \%$ of Italians were illiterate and this figure reached $90 \%$ in the south and on the islands. It was only in 1901 that the $40 \%$ literacy threshold was crossed (Vasta, 1999).

A network of lower and upper primary schools, each lasting three years, emerged from a survey on the Italian education system conducted in 1864 . The subjects of the lower primary schools were reading, writing, elementary arithmetic, Italian, elementary notions of the metric system, and religion. In addition to the lower educational plan, the upper primary schools included rules of composition, calligraphy, bookkeeping, elementary geometry, national history, physical and natural sciences applied to the ordinary uses of life, elements of geometry and linear drawing for boys and "women's activities" for girls. The lower school could not be attended before the age of 6; it was compulsory for both boys and girls and each municipality had to have at least one school for each sex. The teachers were chosen by the municipalities from a shortlist of candidates (men aged 18 years and over, women 17 years and over) who had passed a proper qualifying examination (Ministero dell'Istruzione Pubblica, 1866: 33) ${ }^{5}$.

In drafting statistics and reports, however, government offices tended not to distinguish between lower and upper primary schools, instead highlighting the boy-girl or public-private distinction. The school network was particularly articulated in Piedmont and Lombardy. Of the 15,151 public primary schools for boys registered in 1864 for the entire Kingdom, 3,264 were located in Lombardy, in second place after Piedmont with 3,982. The position of the two compartments was reversed when counting boys' private primary schools: 274 in Lombardy against 133 in Piedmont, out of 3,159 in all of Italy. This meant that out of the total of 18,310 public and private primary schools for boys registered in 1864, 3,538 were in Lombardy and 4,1 15 in Piedmont. The compartment which followed Lombardy and Piedmont was Tuscany with 1,735 primary schools for boys (864 public, 871 private), followed by Emilia with 1,659 schools (1,339 public, 320 private) and Campania with 1,374 schools (987 public, 387 private). These were therefore significantly lower numbers than the "leading" compartments of Piedmont and Lombardy. As for the girls' situation, there were 13,494 primary schools (9,848 public, 3,646 private) in Italy in 1864, of which 3,452 were in Lombardy (2,674 public, 778 private), 3,087 in Piedmont (2,697 public, 390 private), 1,302 in Tuscany (376 public, 926 private), 1,203 in Emilia (715 public, 488 private) and 913 in Campania (696 public, 217 private). In gen-

5. For a complete analysis, see also SOCIETÀ DEGLI AGRICOLTORI ITALIANI (1901), Bidolli and SOLDANI (2001). Furthermore, from the analysis of the school activities described in the bulletins to which we will return in the following pages - it emerges that Lombard teachers were both men and women equally inclined to involve students in practical educational activities. 
eral, the primacy of Piedmont and Lombardy in boys' education was mirrored in girls' education, with the difference that in this sector the absolute primacy belonged to Lombardy (Ministero dell'Istruzione Pubblica, 1866: 34-5) ${ }^{6}$.

It is also necessary to take into account the difference between primary schools in urban and rural municipalities, using the number of 6,000 inhabitants as a cut-off point. In $1864,7,139$ primary schools were registered in urban areas and 24,485 in rural areas, which speaks volumes about the ruralisation rate of Italian society. Specifically, in Lombardy there were 3,177 rural schools for boys and only 361 urban ones; there were 2,789 schools for girls in rural areas and 663 in urban areas. In Piedmont, there were 3,658 rural schools for boys and 457 urban ones, 2,500 rural schools for girls and 587 urban ones (Ministero dell'Istruzione Pubblica, 1866: 37-8).

In the same year, 156,621 boys and 131,754 girls were registered in public primary schools in Lombardy, out of the 597,202 boys and 440,627 girls of Italian public primary schools. As for public teachers, Italy had a teaching staff of 14,887 men and 10,122 women, to which the Lombardy compartment contributed with 3,143 and 2,578 teachers respectively (Ministero dell'Istruzione Pubblica, 1866: 40-1, 49-50).

In 1864, the Kingdom of Italy still lacked some geographical areas characterized by a very good network of primary schools, which together with the strengthening of the Italian teaching offer would further articulate the statistics. Consider that if in SY 1863-64 the Lombardy compartment had 5,721 primary school teachers (Carina, 1871: 47), in 1881-82, almost twenty years later and after the addition of Mantua to Lombardy in 1866, there were 6,725 teachers in lower and upper public primary schools. The Veneto compartment, annexed to Italy in 1866, had 4,451 teachers in 1881-82 (Carina, 1871: 67). Finally, in SY 1901-02, Lombardy had 8,062 teachers in lower and upper primary schools, the Veneto compartment including Friuli had 5,193 teachers and Piedmont 7,280 (Carina, 1871: 88; Vigo, 1971: Appendice statistica) ${ }^{7}$.

6. In 1854, 2,457 public schools for boys and 1,936 public schools for girls in Hapsburg Lombardy had been registered (VIGO, 2012: 101). However, this situation did not perfectly match the homonymous compartment of the following Kingdom of Italy, for example the lands of Oltrepò Pavese were excluded from Hapsburg Lombardy as they were part of the Kingdom of Sardinia and dependent, like Piedmont, on Savoy policies.

7. In general, in SY $1875-76$ the differences recorded by the Ministry of Education were already relevant for macro-areas, marking the difference between Northern Italy (Piedmont, Liguria, Lombardy and Veneto) with a public or a private primary school every 443 inhabitants, Central Italy with one every 571 inhabitants, Southern Italy with one for every 698, and Sicily and Sardinia (the socalled "Insular Italy") with one school for every 936 inhabitants: (MINISTERO DELL'ISTRUZIONE PUBBLICA, 1878: 13). 
As for technical secondary education, this was divided between three-year technical schools and subsequent three or four-year technical institutes, depending on the chosen path. The technical schools taught Italian, history and geography, French, mathematics, drawing, calligraphy, natural sciences, and business maths. As expected, the hours of technical lessons increased sharply during the three-year period. This type of school was designed both for those wishing to pursue technical-scientific education and for those wishing to work directly as entrepreneurs, traders or industrial managers. The trend favoured the latter, so much so that the technical schools were often considered as professional schools and preferred by the families of the lower middle class compared to the humanistic classical schools (ginnasi and licel) (Ministero dell'Istruzione Pubblica, 1878: 117-20) ${ }^{8}$.

In SY 1874-75, in Piedmont and Lombardy the "royal" technical schools (managed by the government with the contribution of the municipalities) numbered 18: 7 in Piedmont and 11 in Lombardy; another 18 were in Sicily alone. The picture was more complex considering the 241 Italian technical schools under municipal management only, with the primacy of Piedmont (36 schools), followed by Emilia (31 schools) and Lombardy (25 schools) (Ministero dell'Istruzione Pubblica, 1878: 121-2).

Then there was the vocational education system, which was the mix of the so-called "arts and crafts" schools. In 1871, the politician and pedagogist Dino Carina (Cherubini, $1977)^{9}$ drew up a national report on the matter, after careful investigation on behalf of the Ministry of Agriculture, Industry and Commerce. In Italy there were 154 schools in those years, with a total of 567 teachers and 13,329 pupils, on which 1,417,022 lire were spent. It was a varied scenario, in which there were both contemporary schools and oldfashioned ones, some with young pupils and others with adult students, following different teaching strategies. Moreover, some schools embraced the entire vocational education without many distinctions, while others focused on specific branches of industry and manufacturing, for example the textile sector (Carina, 1871: 66). Therefore, even more than primary schools, arts and crafts schools represented the fragmented nature of the Kingdom well. In many cases, in fact, these were institutions that dated back to pre-1861 Italy, sometimes founded by the government, sometimes by private individuals. In the same years in which Carina wrote, the economic support came in some cases from the "enlightened zeal of public representations", in other cases from the "philanthropic wisdom of capitalists and entrepreneurs", therefore still retained the didactic and institutional anarchy of the previous decades (Carina, 1871: 66).

8. Cfr. Genovesi (1993), Bonetta (1996). On the popular agricultural press, see in a comparative key BARGELLI (2013).

9. Cfr. Patriarca (2010: passim). 
Carina recognized the need for homogeneous coordination by the Italian government. First of all, to guarantee subsidies to those schools willing to improve their educational plans. In addition, they should all focus on theoretical teaching, while practical teaching should be limited to workshops and factories. The arts and crafts schools should be located close to them, so as to guarantee interaction between the theoretical and practical centres of a technical area, without, however, confusing the respective spaces.

According to Carina, it was also necessary to frame arts and crafts schools in the national education "organizational chart", in order to avoid confusion and overlapping with primary and technical schools. He believed that arts and crafts schools should be defined "only those that involve the teaching of some scientific or artistic disciplines adapted to the needs of local industries". He therefore stressed that the importance of this category of teachings had relevance especially for the local industry. Moreover, regarding the most appropriate age group, Carina advised that they be children and young people who had received primary education, so that they could participate in a longer and structured program, given that he considered evening lessons for adults as mere in-depth or recovery classes. Finally, he suggested the parameters according to which the government could distinguish the arts and crafts schools from the others, guaranteeing adequate funding and providing teaching material for demonstrations in the classroom, perhaps by erecting a specific central establishment (Carina, 1871: 70-7).

Nonetheless, beyond these general guidelines, the centralization of arts and crafts schools should not go further. As for the educational programs, according to Carina, the government should only impose the teaching of Italian, general culture, principles of political economy, decorative drawing and industrial design, to allow the future workers "to express their thoughts and to understand those of the colleagues [...] in order to call our [Italian] industries to the observance of artistic precepts that they sometimes seem to forget". Imposing further subjects at the expense of the peculiarities of each geographical area "would probably damage what should be initiatives shaped by the local industry", flattening a program that had variety as its main characteristic (Carina, 1871: 72-3).

If the Ministry of Education took care of reforming the Italian primary school system, it was teachers, business associations and municipalities that stimulated the interest of the youngest and least educated towards agriculture through educational initiatives, competitions, refresher courses and popular publications. The importance of these initiatives stood out in a particularly unstable socio-economic context, characterized by migration, pockets of misery in rural areas and poor agricultural entrepreneurship. Undoubtedly, a process of modernization was developing, linked to the increase in infrastructure and the beginning of industrialization. However, industrial activities were concentrated in the north 
and mainly concerned the manufacturing sector. Not to mention that in general most of the peninsula was disadvantaged due to the lack of raw materials, a credit and financial system which was still in development and a cultural framework which was not suited to the structural change of the economy (Fontana, 2011; Pini, 1991; Sasso, 1985).

It was therefore important to focus on the main productive sector in Italy: the agricultural sector. On the one hand, adequate training was required for technicians who would be engaged in a sector that now covered an unprecedented surface and that was gradually accepting the progress of science, for example in the field of applied chemistry. On the other hand, it was important to transmit the greatest number of correct agricultural notions to rural society. However, there was no structured or centralized planning of agrarian education at the various school levels. Therefore, the first proposals were an initiative of the provincial school councils, but above all of the individual schools, of the municipalities they reported to and of particular associations devoted to strengthening local agriculture and animal husbandry. This relative freedom linked to local institutions had the useful result of adapting the first forms of agricultural education to the resources of individual territories.

It is however important to remember that a decisive role in educational policies and particularly in the education of the rural masses was given by the governments of the socalled "Historical Left" led by Agostino Depretis (1813-87), one of the main parliamentary fronts that characterized late- $19^{\text {th }}$-century Italian political life. In those years, in fact, the debate on primary education was intense, at the time regulated by the Casati Law of 1859. In his speech on $11^{\text {th }}$ October 1875 Agostino Depretis stated: "Let me tell you that I consider it urgent to pass a law as soon as possible declaring compulsory and free primary education to be entrusted to the laity" (Maffi, 2012a, 92). Along with the extension of electoral suffrage, free and compulsory primary education, with the consequent fight against illiteracy, was one of the focal points of the electoral program of the Historical Left. On $15^{\text {th }}$ July 1877, just over a year from the beginning of the first Depretis government, the Minister of Education Michele Coppino succeeded in approving the law on the obligation of primary education. The previous law had been the Casati Law of $13^{\text {th }}$ November 1859, which in 380 articles had organized in detail the education of the Kingdom of Sardinia at all levels of education (immediately extended to the rest of the peninsula).

The Casati Law divided primary education into one compulsory two-year period and one non-compulsory two-year period (articles 315-316); the municipalities had to guarantee education (articles 317-318). With education being compulsory, the penalties for non-compliance were clearly indicated (article 326). The Coppino Law increased school 
attendance by one year (6-9 years); once again, the municipalities had to guarantee teachers and services, and the penalties for non-compliance increased. The subject "notion of the duties of man and citizen" appeared instead of religious teaching. In fact, municipalities had to ensure this teaching if requested by parents. The Coppino Law partly reduced the gap between municipalities in the north and south, regarding compulsory education and active teachers (Maffi, 2012a: 92-3; Brignoli \& Colombo, 1988: 95-101; Morandini, 2001).

\section{TEACHING AGRICULTURE IN THE MONZA AREA}

Our first case study is the introduction of agricultural teaching in the primary schools of the Monza area, near Milan, during the last three decades of the $19^{\text {th }}$ century. The initiative involved two main agents. On the one hand were the teachers, who were well aware of the need to explain the basic notions of agricultural activity but had generally not planned for primary school programs. On the other hand was the Comizio Agrario of Monza, which shared the same awareness as the teachers regarding the lack of -and the need for- basic agricultural education. The Comizio also produced didactic and illustrative texts on the subject, rewarded the most enterprising teachers in this field and advertised their initiatives through its own bulletin ${ }^{10}$.

What were the aims of the Agrarian Committees? They were associations that had their roots in the Kingdom of Sardinia, such as the Subalpine Agricultural Association (Associazione Agraria Subalpina), founded in Turin in 1842, which brought together groups of intellectuals, landowners, and politicians of both noble and bourgeois extraction. The objectives of the Subalpine Association were to improve the conditions of agriculture, livestock, and rural society by spreading agricultural techniques and a general cultural improvement. The first pre-unification comizi agrari had therefore been representative of the Subalpine Association itself. Later, with the birth of the Kingdom of Italy in 1861, a royal decree at the end of 1866 confirmed the presence of the comizi. The same decree added the obligation of having a comizio in every district capital (the districts were territorial en-

10. We also recall the situation of illiteracy in 1860 s Italy, because of which there is a considerable lack of direct evidence coming from the rural population, as is clear from the nature of the primary sources used in this article: printed bulletins and other texts edited by institutions and educated people. In a comparative key, an interesting case study is the one proposed by historiography for Brazil: having ascertained the scarcity of documentation written by the rural population and especially by slaves in almost all of the $19^{\text {th }}$ century (official abolition of slavery in 1888), Eduardo Silva considered how it is possible to guess traces of the camponesaresistance from the $19^{\text {th }}$-century agronomy treaties (for example, Memoria sobre a fundação e costeio de uma fazenda na província do Rio de faneiro, written by fazendeiro Barao do Paty do Alferes, and published in 1847). Cfr. Silva (1989). 
tities belonging to the provinces; for example, the district of Monza belonged together with others to the province of Milan) (Maffi, 2012a: 64; Saltini, 2006).

The issues of the bulletin of the Comizio of Monza provide us with descriptions of a gradual introduction of basic agrarian education into the Monza schools from the $1870 \mathrm{~s}$ to the $1890 \mathrm{~s}^{11}$. This kind of teaching provided the main notions to an audience of children, avoiding a boring approach and indeed offering outdoor didactic workshops with the dual objective of involving the lively class and consolidating the concepts learned.

In 1875, the Comizio of Monza awarded some prizes to the teachers who were willing to explain "agriculture" in their classes, some of whom had already started the program in previous years. At this first level of the work, emphasis was placed more on quantity than quality. The initiative started with the Comizio, which provided the teachers with didactic material, small books, and pamphlets on various aspects of agricultural activity; the intermediaries in this case were the mayors, who acted as a link between the "central management" of the Comizio of Monza and the schools in smaller towns. Prizes were still planned for the teachers who agreed to be part of the initiative and for those who knew how to find a particular interpretation.

In the following years, agrarian education in the Monza area was the object of great interest. In 1876, the Comizio awarded the teachers, an assistant, and the pupils of three towns who had introduced agricultural science in 1875 with a total of 199 lire (Cascina Bastoni, Concorezzo and Cinisello). In 1877, noting the success in these three towns, the schools of Brugherio and Monza also declared their interest in inserting basic agricultural education in the educational program.

A clear change took place in 1877. It was no longer the Comizio of Monza that urged teachers to evaluate the proposal, but the schools themselves which turned to the Comizio to collaborate in the project -and possibly compete for awards. Furthermore, every year the importance of meeting rural society's needs in the field of education too was clearer and clearer, adding to the traditional subjects lessons which were more coherent with their living environments and future jobs. Everything had greater fluidity due

11. In SY 1862-63, there were 186 primary schools in the Monza circondario, including 107 boys' schools and 79 girls' schools distributed in the various municipalities; in the municipality of Monza alone, there were 17 schools. There were 186 teachers in the circondario for 15,457 pupils; in the municipality of Monza alone there were 17 teachers for 1,079 pupils (Ministero dell'Istruzione Pubblica, 1865: 124-5). The Italian circondario was an administrative division between the provincial and the mandamento level (a group of municipalities). The main city of the circondario was also generally at the head of the most important municipality. 
to the lack of a centralized system of primary education. This was fully managed by local authorities, teachers, and other experts. In this last case, the Comizio also organized educational and refresher courses for all ages and more specialized audiences: in 1875 it promoted a series of conferences on sericulture held by the engineer Luigi Frigerio, but also visits to particularly productive estates to encourage smaller farmers to improve their strategies ${ }^{12}$.

A twofold testimony published in the bulletin dates back to those same years, in which the mayor of the town of Velate Milanese presented a letter from a primary school teacher from Usmate, a town in the Monza rural area, which had been merged with Velate ten years earlier. We are in 1878: despite the fact that the bulletin is from July, the letter from the teacher (Federico Fracaro) is dated in March. It is a detailed report of the didactic program developed over the preceding months for agricultural education both in the classroom and in orchards.

Mayor Rinaldo Casati praises this initiative by highlighting the fact that schoolchildren are educated by their teachers in the first and most necessary knowledge of agriculture. In particular, he notes that young people are informed about the cultivation of the soil and of those agricultural products that are mainly in use in this rural area, including for example the sericulture sector. In addition to the theoretical aspects, their learning is also stimulated by practice; in fact, through the laboratory-type approach, Fraccaro gathers his students in the vegetable garden that he cultivates near the school. This activity often takes place on Thursday, which is a non-working day, proceeding with continuous training in the practice of elementary operations and in the management of the most necessary tools for agricultural knowledge ${ }^{13}$.

Fraccaro himself describes the subdivision into theoretical and practical programs in a more specific way, saying that the elements of agriculture are not part of the didactic program, but the teachers, who carry out this extra activity, transmit information to their students on breeding and dairies, mulberry growing and sericulture, fertilizers, cultivation of cereals, root crops, forage plants, and vines ${ }^{14}$.

12. Bollettino del Comizio Agrario Monzese, (4) 1, 1878, pp. 7-10. Frigerio was involved in mulberry plantations and sericulture, but also in other operations associated with silk spinning, weaving, and colouring. His company was present at the Italian Industrial Exhibition in Milan in 1871: Guida ufficiale, p. 17, he is the exhibitor No. 42 and shows egg albumin and blood albumin to set the colours of fabrics.

13. Bollettino del Comizio Agrario Monzese, 4 (7), 1878, p. 9.

14. Ibid., pp. 9-10. 
Two very important traits emerge from Fracaro's report. First is the exceptional nature of the lessons he taught in the field of basic agricultural education, so much so that he had to bring the students together at school on the traditional midweek holiday. Second is the importance given once again to mulberry growing, which had been one of the main resources of Upper Lombardy since the $17^{\text {th }}$ century. (Corritore, 2012; De Marchi, 2009; Federico, 1997; Moioli, 1981; Romani, 1957, 1963). The importance of mulberry cultivation, silkworm breeding and silk manufacturing was therefore stressed in primary school from the first year.

Indeed, as pointed out by Claudio Besana a few years ago, according to the contracts of the time in Brianza, tenant farmers generally earned very little from mulberry cultivation, silkworm breeding and silk manufacturing. These activities were widespread from 1815 , so much so that the landowners -who were the only ones to earn from themdedicated large portions of their properties to them. This was a situation that persisted in the mid-19 ${ }^{\text {th }}$ century, leaving the tenant farmers in poverty. Nonetheless, Besana notes that there were no explicit manifestations of peasant protest, perhaps partly due to the excellent performance of the silk chain, which somehow benefited even the poorest class. Besana also notes that the landowners declared themselves willing to give direct assistance to tenant families in difficulty. At the silk manufacturing level, the situation was different depending on the area in Brianza and the processing stage. In general, however, in the first half of the $19^{\text {th }}$ century factories and industrial-scale production were becoming widespread at the expense of "domestic" manufacturing (Besana, 2007: 55-77).

The needs highlighted by teachers like Fraccaro paved the way for the action of the Comizi. For example, between 1875 and 1876 the Comizio constituted examination commissions to assess the necessity of basic agricultural education in all the municipalities of Monza area and to analyse any projects already started. A statement appeared in the bulletin at the beginning of 1876: the teachers were urged to undertake theoretical and practical agricultural teaching, combining explanations with "trips to fields and gardens". In the summer of 1878, the list of visits made by the schools of Monza was published, in which sometimes the younger pupils joined the older ones or even high school students (given the technical complexity of some topics). During those visits, the pupils saw farmyard animals, received practical botany lessons, were shown the structure of a gasometer and the operation of a furnace, with the teacher often assisted by specialists such as botanists and engineers ${ }^{15}$. This kind of program brought out the link between agriculture, manufacturing, and industry. At the same time, it highlighted the desire to introduce practical lessons that took the resources of the territory into consideration. The

15. Ibid., pp. 10-2. 
ultimate -and large-scale- goal was the economic development of the Kingdom of Italy illustrated at the beginning of our intervention.

This didactic enthusiasm suffered a setback in the early 1880s. In fact, in March 1883, through the bulletin, the Comizio of Monza still urged municipalities and teachers to foster the teaching of the "first subject in the world, agriculture, which provides nourishment to humanity". Nonetheless, it complained that basic agrarian education was still "roughly provided in Arcore, Brugherio, Usmate and Velate", in a situation more or less similar to that of six years before ${ }^{16}$.

The novelty in these exhortations was a renewed interest in livestock, whereas in the 1870s the most privileged area had been crops. Indeed, in 1883, the Comizio of Monza launched a campaign for the formation of a "Scholastic League for the protection of useful animals". In particular, they addressed the teachers several times to introduce them to the initiative. Among the few examples shown there was once again Federico Fracaro: a detail that on the one hand honoured the individual, while on the other indicated a diffusion of the initiative which was not yet optimal ${ }^{17}$.

The Comizio also paid particular attention to the agricultural education systems adopted abroad, of which the bulletin reported up-to-date news. For example, regarding the circulation of useful notions dedicated to adults already working in the agricultural sector, the Comizio underlined the case of the Agricultural Society of Hesse and its extensive agricultural education network. The Society was private but subsidized by the government; the president was chosen by the government and was head of the Department of Agriculture of the Ministry of the Interior ${ }^{18}$. It was therefore evident that the Comizio of Monza desired greater participation of the central government in the planning of agricultural education, which also needed a more solid structure. This desire also emerged in the veiled criticisms already cited concerning the "roughly provided" teachings. A very different approach from that recorded in the 1870s, when the fluidity of the educational programs managed by teachers, municipalities and other institutions seemed instead appreciated by the Comizio. Probably, having noticed the stagnation of agricultural education in schools, it began to hope for a different strategy, systematically imposed "from above".

16. Bollettino del Comizio Agrario Monzese, 9 (3), 1883, p. 4.

17. Bollettino del Comizio Agrario Monzese, 9 (6), 1883, p. 15, where we can find a reference to a circular letter published that same year, in the February issue, p. 12.

18. Bollettino del Comizio Agrario Monzese, 9 (6), 1883, pp. 11-2. 
In addition to soliciting a change in teaching plans through competitions and praise, the bulletin also reported educational articles on various topics of agricultural activity, using concise language which was as clear as possible, sometimes using narrative passages and inserting excerpts of dialogue to better involve the reader. This strategy was typical of self-help literature and in vogue in the moralizing stories spread in those years in the working classes of the big cities (Marazzi, 2014; Chemello, 1991; Chemello, 1997: 18892). A good example is a text on the conservation of manure that appeared in episodes during 1893, taken from the series "L'agricoltura propagata ai figli dei campagnuoli" (Agriculture propagated to farmers' children) of the Gazzetta Agricola. The Gazzetta was one of the many agricultural and educational journals collaborating with the bulletin in a real "press network". The serialized text is structured as an interview with a fictitious farmer, who explains to the interviewer the best procedures for conserving manure, being more open to chemical fertilizers, whose use "is increasing", but recommending caution in their purchase to avoid falling afoul of scams ${ }^{19}$. The result was a balance between traditional methods and cautious openness to modernity. The balance between manure and chemical fertilizers is actually a metaphor for the attitude of agriculture and animal husbandry in post-unification Italy, torn between innovation and circumspection.

After education, another analysis is dedicated to raising awareness of rural society in the field of sanitation regarding both human health and livestock. Both were particularly critical topics in the Italian countryside, as recorded by the parliamentary inquiry that analysed the state of agriculture and rural society in Italy from 1877 to 1886, under the coordination of Stefano Jacini during the government of Agostino Depretis (Cosmacini, 2016; Ferrari \& Mazzarello, 2010; Frascani, 1984; Corti, 1984).

In this, the Comizio of Monza was once again very active. It collaborated with various state bodies, starting from the basics: physical education in schools, hygiene, and basic health care. For example, at the end of the 1870s it gave its full support to the Monza School Superintendency's campaign in favour of physical education inside and outside the classrooms, with both indoor gymnastics and frequent excursions in the countryside, villages, and farms, in order to obtain complete well-being for the body and the mind (mens sana in corpore sano $)^{20}$. However, the importance of physical education supported by the Superintendency's campaign was not limited to primary schools: it extended to

19. For the first episode, see Bollettino del Comizio Agrario Monzese, 19 (3), 1893, pp. 9-11, by R. Ghidoni.

20. Moreover, in those years the boys' schools of the Monza area introduced the Jäger stick, a simple and economic tool that allowed a wide range of gymnastic exercises. Bollettino del Comizio Agrario Monzese, 4 (3), 1878, p. 3. 
kindergarten, obviously with the necessary proportions and adjustments aimed at reducing the difficulty of the exercises ${ }^{21}$.

The constant stimulus by the Comizio to clean and maintain stables was also part of the sanitary and hygiene support. In this regard, the bulletin published excerpts from veterinary and animal husbandry magazines and organized meetings with experts. The first goal was to raise awareness on the issues of protecting livestock from all types of disease and from the epizootic waves that still affected the Italian countryside, especially in the absence of adequate veterinary prophylaxis. Secondly, in addition to the serious damage caused to national economy, unhealthy environments and infected livestock created dangers for human health. With the passing of the 1890s, the Comizio recorded an improvement in the sanitary conditions of the countryside: a success once again due to the combination of the authorities' commitment with rural society's active participation ${ }^{22}$.

\section{TECHNICAL AND PRACTICAL EDUCATION IN OLTREPÒ PAVESE}

When it comes to Oltrepò Pavese, the area to the south of the river Po, we must turn our attention to the Comizio of Voghera. As in the case of Monza, one of its main objectives was to disseminate the most up-to-date knowledge in the primary sector. Once again, it wanted to foster the development of skills that would allow farmers to improve their economic and social conditions and participate in Italian progress. The bulletin of the Comizio of Voghera repeatedly expressed these goals and, in order to support their realization, instituted prizes for the primary school teachers who taught practical elements of agriculture, as well as for agrarian conferences and other initiatives. The educational goal, therefore, was not intended only for members of the association, but extended to the entire population, at the time largely employed in the primary sector. From this point of view, these guidelines were similar to those followed in Monza. However, it is important to see how these initiatives were adapted to the characteristics of the Voghera area.

The interest of the Comizio in agricultural education in primary schools and its social value is particularly clear in a circular letter dated $5^{\text {th }}$ September 1876 . The members unanimously agreed on some prizes in favour of teachers who would effectively teach agriculture in their schools during SY $1876-1877^{23}$. The Comizio also distributed free

21. Bollettino del Comizio Agrario Monzese, 6 (1), 1880, pp. 7-10. Cfr. BonetTa (1990).

22. Some examples in Bollettino del Comizio Agrario Monzese, 18 (1), 1892, pp. 20-3; 19 (12), 1893, pp. 13-5; 20 (1), 1894, pp. 14-7; 20 (2), 1894, pp. 10-4; 21 (4), 1895, p. 19.

23. In SY 1862-1863, the circondario of Voghera had 201 primary schools, with 9,744 pupils as- 
copies of the Trattato elementare di agricoltura (elementary treaty of Agriculture) (Podestà, 1876) written by Professors Podestà and Pasotti. The book was given to teachers who had already taught basic notions of agriculture in the previous years, encouraging them to continue educating students in that field ${ }^{24}$. Moreover, in 1870 , the Comizio launched a competition for the writing of an agriculture manual for the preparation of teachers and consequently for teaching in schools. As in the Monza area, in Voghera this teaching of agricultural theory and practice would not be curricular: it was a furthering of knowledge with a strong social and educational value.

The role of the Comizio of Voghera is even more significant considering their work to provide basic agricultural education at the primary school level. Also in the light of what we illustrated at the beginning of our article regarding the educational system in those decades, the social and educational function of a scholastic path that allowed pupils to discover the connection between the people and their territory was evident. The goal was to offer elementary knowledge about agricultural activities, as well as about customs and habits of the places in which the pupils lived.

In the same issue of the bulletin quoted above, Giuseppe Pasotti, secretary of the Comizio $^{25}$, published an article entitled "Agricultural education in teachers' colleges and primary schools". He emphasized the fundamental role of agricultural knowledge for social prosperity in regions with a flourishing agriculture. He also complained about the widespread habit of thoughtlessly imitating the ways and habits of ancestors, avoiding anything new in either cultivation methods or mechanical instruments.

Pasotti was a supporter of agricultural education at all school levels, claiming that cultivating fields was an art that required not only practical rules, but also theoretical knowledge. In Italy, this knowledge was not yet widespread, due to the fact that there were agronomic schools for only "a few" citizens, while the principles of agricultural techniques should have been part of everyone's education. Another innovative and essential aspect is related to the fact that Pasotti considered teacher training essential. A teacher who was going to spend his life among rural populations needed to know agricultural practices. In

signed to 195 teachers. In the municipality of Voghera there were 17 schools, 1,017 pupils and 23 teachers. The municipality of Stradella -to which we will return by analysing the practical school for cellarmen-was also part of the circondario of Voghera, with 15 schools, 679 pupils and 15 teachers (MINISTERO DELL'ISTRUZIONE, 1865: 156).

24. Bollettino del Comizio Agrario Vogherese, 13 (9), 1876, pp. 244-45.

25. Giuseppe Pasotti was a teacher in the secondary school of Voghera, as well as secretary of the Comizio for many years; later he became headmaster of the normal school for women of the Province of Pavia and then head of the School Superintendency of the province of Mantua. 
fact, the teacher had to support the development of agriculture and rural society, fighting against prejudices, correcting incorrect systems, and giving wise advice ${ }^{26}$.

Both in Pasotti's opinion and in the rural elites' propaganda, the concept of novelty contrasted with that of tradition. From bulletins and other texts emerged the devaluation of "ancestral" agricultural practices and the criticism of farmers' rejection of the chemical and technical improvements proposed "from above". Obviously, this was only one side of the debate. It would be interesting, from this point of view, to make a comparison with very different situations from the Lombard one. In England, for example, in the $18^{\text {th }}$ century the rural population had showed little appreciation for the attempts by the authorities to discipline workers through education (Thompson, 1967: 56-97) ${ }^{27}$. On a more general theoretical level, in 1985 the anthropologist James C. Scott inserted similar bottom-up oppositions -valid for the past as well as for the present- in the concept of "micro-resistance" and "weapons of the weak", describing these practices in a contemporary Malaysian village $(\text { Scott, } 1985)^{28}$.

In Brazil, the "tradition-novelty" contrast in the rural education scenario took on an anti-colonial identity and value. In a very different historical context from the Italian one, Brazil inherited the legacy of a colonized land, exploited and plagued by centuries of slavery. Education in the Brazilian countryside in past decades is considered by the educação do campo movement -which has developed in the last three decades- as a means traditionally used by elites to control peasants. An alternative educational proposal, which enhances traditional knowledge and its transmission putting the farmers at the centre of agricultural economy, is the basis of the educação do campo to develop other production models, such as agroecological and socialist one ${ }^{29}$. Brazil's particular historical and contemporary situation makes it possible to understand that education and "progress" imposed from above may have different implications and effects, depending on the context in which they are inserted.

26. Bollettino del Comizio Agrario Vogherese, 13 (9), 1876, pp. 246-50.

27. Thompson used sources such as laws and bulletins for his study, but also songs, given the lack of direct written sources.

28. Eric Hobsbawm also approached a similar concept of bottom-up resistance in history from several points of view. Regarding some of his most significant interventions in this direction, we recall some classic titles: HobSBAwm (1953, 1964, 1973, 1998).

29. These topics have been the subject of careful historiographical investigation in recent decades. In this regard see ARroyo (1999), CALdART (2000, 2004, 2009), CALDART et al. (2012), CAMACHO (2014), Fernandes and Molina (2004), Fernandes (2011), LaCERda and SANTOS (2010), Mariano (2019), Molina (2017), Esteves de Oliveira (2014), and Pereira de Queiroz (2004). 
This is not to say that resistance was conscious and widespread in the Italian case studies in this article. As we have tried to highlight, despite the different results of the educational initiatives in the areas of Monza and Voghera, there was good collaboration between parties. As regards Carina's comments on arts and crafts schools, we recall his support for educational institutions to be linked to local activities, in which government interference would be limited because it was harmful to industries, enterprises and the local working class. According to his theory, arts and crafts schools should enjoy relative autonomy, especially in didactic programs, which we can conclude would preserve them from homologation on a national scale.

In Voghera, the interest in elementary agricultural education continued in the following years, stimulated by the diffusion of the Trattato by Podestà and Pasotti sponsored by the Comizio. The treaty did not limit itself to local diffusion. On the contrary, it had didactic and educational value on a larger scale: it even won prizes at a national level, as shown by the awarding of the silver medal at the $10^{\text {th }}$ Italian Pedagogical Congress in Palermo ${ }^{30}$. The Comizio therefore supported the diffusion of the book among the primary school teachers in towns and rural municipalities of the Oltrepò Pavese and provided prizes that encouraged this educational effort. An ad hoc committee evaluated the work of the adhering teachers for a number of school years, writing the related "Report on Agricultural Education"31. The number of teachers who participated in the initiative was not high, but enough to enable real pedagogical and didactic experimentation on primary school teaching. The supervisor was Pasotti himself, who in the Trattato wrote the chapter "Guide to the teaching of agriculture for the use of elementary school teachers"32 and later published detailed agricultural programs for schools ${ }^{33}$.

The Comizio supervised the agricultural teaching in primary schools through its delegates, also on the mandate of the provincial school council. For SY 1885-1886 we can read the following information:

30. Bollettino del Comizio Agrario Vogherese, 13 (8), 1876, p. 270.

31. See the following reports: Bollettino del Comizio Agrario Vogherese, 15 (11), 1878, pp. 557-61: "Relazione presentata all'onorevole Giunta del Comizio Agrario di Voghera dal Prof. Giuseppe Pasotti sopra l'Istruzione Agraria impartita nelle Scuole Elementari del Circondario nell'anno scolastico 1877-1878"; (17), November-December 1880, pp. 267-78: "Relazione sull'insegnamento agrario impartito nelle scuole primarie del Circondario di Voghera nell'anno scolastico 1879-1880"; (18), November-December 1881, pp. 335-41: "Relazione sull'insegnamento dell'agricoltura elementare impartita nelle scuole primarie del Circondario di Voghera nell'anno scolastico 1880-1881".

32. Podestà (1876: 453-571).

33. Bollettino del Comizio Agrario del circondario di Voghera, (29), September-October 1893, pp. 83-9. 
"In this year, agricultural teaching was provided in 35 municipalities of the province - that is in 29 of the district of Voghera, in 3 of the district of Bobbio, and in 3 of the district of Mortara, and Lomellina. Almost all the municipalities belong to the district of Voghera, and the Comizio Agrario had some influence, as it offered a prize for a teaching manual and later organised lectures and courses for teachers. According to these reports, there are 6 municipalities in the district of Voghera which have land for exercises; of the teachers who taught agriculture, 5 were from normal schools and 24 had only attended agrarian conferences. The sum of the prizes granted to them is 1,170 lire and the number of students who attended these schools is $1,228^{\prime \prime 34}$.

In Voghera, after thirty years of difficulties of secondary technical education in the agricultural sector, the Royal Practical School of Agriculture opened its doors in 1895 (Maffi, 2012a: 108-17). The institute immediately distinguished itself for a strong interest in the most recent progress in the agricultural and agri-food sector, integrating rigorous theory with field experiences. One of these was the visit organized for students of the second and third grades of the upper course to the viticulture section of the 1898 Italian General Exhibition. Agricultural fairs and industrial exhibitions on both local and national scales were great opportunities to update students, workers, farmers, and entrepreneurs: a value that all the Italian Agrarian Committees were aware of ${ }^{35}$.

The main pavilions of the 1898 Exhibition were in Turin, but the part dedicated to the wine sector was symbolically located in Asti, in the areas of the Langhe and Monferrato famous for the production of grapevines and wines. As Asti is not too far from Voghera and the two were served by a good railway connection, the students of the Royal School went by train at the beginning of June 1898 and wrote a series of reports on the visit, describing the Exhibition and giving their impressions on the subject. The Comizio of Voghera had promised a prize for the best report: the winner would be the student who produced the most original observations on the visit and proposals for possible technological applications to the territory.

From the examination of the reports, we understand the effectiveness of the visit as a practical educational experience. The students could directly learn about the most recent technological innovations in the agricultural sector, in this case viticulture, as well as the

34. Bollettino del Comizio Agrario del circondario diVoghera, 26 (3), 1890, p. 63.

35. The Bollettino del Comizio Agrario Monzese was very interested in the National Exhibition of Turin of cattle for fattening, organized at the beginning of May 1870: 6 (6), 1870, pp. 17-20; 6 (7), 1870, pp. 11-4; 6 (8) (supplement), 1870, pp. 11-3. 
best production practices. Stimulated by the teachers, they reflected on the why of things, combining description and interpretation of the landscape in order to understand the organization of the territory, identifying aspects of human-environment interaction. The reports described not only the Exhibition, but also the products on display and the origin of the various equipment. The students showed excellent knowledge of the most famous wines and their areas of origin; a conscious admiration for the innovations of the wine industry was evident, mentioning machines and manufacturing companies (Maffi, 2012b).

Thanks to a complete educational offer and real workshops such as the one that took place in Asti, enrolments at the Royal School of Voghera continued to increase. For example, in SY 1899-1900 the number of students of the upper course reached 48 (Maffi, 2012a: 117).

\section{TEACHING WINEMAKING TECHNIQUES IN THE STRADELLA AREA: A PROJECT}

The progress of winemaking techniques, favoured by mechanical, physical, and chemical innovations, required the formation of a skilled workforce to use the new machinery. Large wine factories, for example, needed specialized workers for the cellar. They had to perform tasks throughout the year, some of which required the development of precise skills. Professional training courses were organized for this purpose, to turn wine education into progress for the territory and a creator of wealth.

In the Voghera and Stradella areas, an opportunity for advancement in viticulture and oenology arose thanks to the Regional Agricultural Competition and the related Exhibition of Pavia in 1877. The ampelographic commissions' aim was to reduce the varieties of grapes grown in the area, as well as to verify the typicality of these varieties in wine production. Through the diffusion of knowledge at local level, the Exhibition favoured the development of skills in numerous wine growers, precisely in the years of great changes for the diffusion of new transport, the need to rationalize crops, and the constant control of cryptogams. In Stradella, where the Italian General Oenological Society had recently disappeared, a new oenological company was active, which used the former's large facility and presented wines that were awarded at the Exposition. This showed that the wine industry had to be supported and that, in a certain way, it had to serve education itself.

Seeing the need to spread wine education, in 1877 the Provincial Ampelographic Commission promoted its teaching at the Wine Company of Stradella. The Comizio of 
Voghera would donate part of the sum that it received from its members and the municipalities ${ }^{36}$. It was decided, taking into account the limited amount that was available, to give two subsidies of 100 lire to two young men between 17 and 20 years of age in exchange for their manual labor in the winery. At the end of each year they would have to provide proof of the skills they had acquired through the theoretical and practical teaching imparted by the Wine Company.

In August 1878 the "Regulations for the admission of cellarman students to the Stradella venue" was published in the Bulletin ${ }^{37}$. The annual sum to be allocated to each student was increased from 100 to 150 lire (article 1). The number of students was still two, with the possibility that the number could be increased in the future (article 3 ). The requirements for admission were to be domiciled in the Voghera district, to be not less than 15 or more than 22 years of age, to be of excellent conduct, to be of robust constitution, to belong to poor families or at least of the working class, and to know how to read and write (article 5). Article 8 stated:

\begin{abstract}
"After completing his course with the favourable report of the director and after having presented proof of his capacity, a certificate of suitability will be issued to the student by the Board of directors of the Wine Depot of Stradella and by the Comizio Agrario of Voghera. They will take an interest in obtaining some advantageous placements for him".
\end{abstract}

At the same time the "Disciplinary regulations for cellar students of the Wine Depot of Stradella" was published ${ }^{38}$. Article 2 showed the skills that young people would learn over the two years: preparation and conservation of wine barrels; different provisions for the pressing and placement of the grapes; different fermentation processes; racking; decanting and overfilling; filtering and clarification; bottling, affixing of corks and labels to bottles; packaging and shipping of wines both in barrels and in bottles; general knowledge on the distillation of marc and wine; cooperage.

History followed another course and the hypothesized scenarios did not materialize. The aforementioned regulations, however, show dynamics and agreements that allow us to understand the desire to spread knowledge and skills in order to prepare technicians who could work in the wine industry. Nonetheless, in the Monografia agraria

36. Bollettino del Comizio agrario vogherese, 15 (11), 1877, pp. 367-70; Bollettino del Comizio agrario vogherese, 15 (7), 1878, pp. 139-40.

37. Bollettino del Comizio agrario vogherese, 15 (8), 1878, pp. 203-05.

38. Bollettino del Comizio agrario vogherese, 15 (8), 1878, pp. 206-07. 
del Circondario di Voghera we can read the following harsh words (Saglio, 1881: 1478):

\begin{abstract}
"We especially wanted to highlight this act by the Comizio because it can be considered as the first attempt made in the Voghera area to have cellarman students. It is with real regret that we observe that so far no candidates have answered the call. Such is the inertia among agricultural populations in terms of education!"
\end{abstract}

\title{
6. CONCLUSIONS
}

The analysis of different teaching paths in the areas of Monza, Voghera and Stradella has allowed us to describe the encounter between the initiatives coming from the comizi and the creativity of teachers and farmers. In this way, we have considered the educational paths that characterized the rural society of post-unification Italy among numerous economic, cultural, and social difficulties. It has been possible to consider the innovative results obtained by a still fairly unstructured organization, paying particular attention to the resources of each territory, while keeping an eye on the most successful innovations from the most advanced countries.

In the considered areas we notice the improvement of the technical agricultural education and its inclusion in the classical didactic programs. The campaigns of dissemination of the comizi and municipalities in the Monza area were unquestionably influential in this. Nonetheless, the teachers' willingness to create practical lessons inside and outside the classrooms for different age groups was even more important. In a society in which dialect predominated and illiteracy would begin to lose ground only at the end of the century, the influence on the rural population was not so much due to the reading of the bulletins per se -read by few educated people- as much as practical activities organized by comizi agrari, authorities and schools. At the same time, professional agronomists who circulated in the Italian countryside educating farmers and landowners were increasingly widespread, paid by Agrarian Committees, chambers of commerce, municipalities, and provincial governments. That was another fundamental means for the diffusion of technical-scientific knowledge in the rural world, to improve both production and the quality of farmers' life ${ }^{39}$. Also the debate on physical education as an essential mean to improve academic performance and awareness campaigns on veterinary prophylaxis took an important position. As the example of Monza represents, thanks to the collaboration be-

39. This topic has been addressed in depth by Italian historiography. We refer here most of all to FUMI and FAILla (2006). 
tween authorities, economic and cultural institutions, and rural society, it was possible to reach the $20^{\text {th }}$ century with a clear improvement in general hygiene conditions.

In the didactic paths, agricultural fairs and industrial exhibitions had an important role. The Asti section of the 1898 Exposition gives an important case: the visit of the students of the Royal School of Voghera was a real workshop of investigation and reflection. The project of the school for cellarmen of Stradella was also part of this pragmatic training context, which sought to propose close complementarity between theoretical and practical training, as in the courses of the Royal School. The failure of the project, however, also emphasizes how in the Oltrepò Pavese the awareness and direct involvement of the rural population in those initiatives was less than in the Monza area. In Brianza, agricultural workshops, the incentives for teachers and students through prizes, the network of conferences relating to different agronomic and zootechnical themes strengthened the collaboration between institutions and society.

\section{ACKNOWLEDGEMENTS}

We thank the editorial board of Historia Agraria and the two anonymous reviewers, who have proved to be of great help with their suggestions, allowing us to improve our study. A very early version of this paper was presented at Rural History 2019, the fourth biennial conference of the European Rural History Organization (EURHO) that took place in Paris in September 2019. To be exact, it was discussed in the second part of the session Rural epistemologies in dialogue: The production of knowledge in peripheral regions in the 19-20 th centuries, organized by Professor Dietlind Hüchtker, from the University of Vienna, and Doctor Corinne Geering, from the Leibniz Institute for the History and Culture of Eastern Europe.

\section{REFERENCES}

Alfani, Guido, Di Tullio, Matteo, \& Mocarelli, Luca (2012). Storia economica e ambiente: Un'introduzione. En Guido Alfani, Matteo Di Tullio, \& Luca Mocarelli (Eds.), Storia economica e ambiente italiano (ca. 1400-1850) (pp. 7-20). Milano: FrancoAngeli.

Arroyo, Miguel (1999). Prefácio. En Edgar J. Kolling, Irmão Nery \& Mônica C. Molina (Eds.), Por uma educação básica do campo, $n .^{\circ} 1$ (pp. 7-9). Brasília: Fundação Universidade de Brasília. 
BARGELLI, Claudio (2013). L'arcipelago del sapere agrario: Agronomia e stampa periodica a Parma nei decenni pre-unitari. Rivista di Storia dell'Agricoltura, (53), 75-108.

BESANA, Claudio (2007). Da coloni a imprenditori: Attività economiche e dinamiche sociali tra Ottocento e Novecento. En Edoardo Bressan (Ed.), Storia della Brianza 2: Economia, religione e società (pp. 55-151). Oggiono: Cattaneo.

BiAnchI, Angelo (Ed.) (2012). L'istruzione in Italia tra Sette e Ottocento da Milano a Napoli: Casi regionali e tendenze personali. Brescia: La Scuola.

Bidolli, Anna Pia \& Soldani, Simonetta (Eds.) (2001). Fonti per la storia della scuola 6: L'istruzione agraria, 1861-1928. Roma: Archivio Centrale dello Stato.

Bigatti, Giorgio (2000). La città operosa: Milano nell'Ottocento. Milano: FrancoAngeli. BIGATTI, Giorgio \& ONGER, Sergio (Eds.) (2007). Arti tecnologia progetto: Le esposizioni d'industria in Italia prima dell'Unità. Milano: FrancoAngeli.

BonETTA, Gaetano (1990). Corpo e nazione: L'educazione ginnastica, igienica e sessuale nell'Italia liberale. Milano: FrancoAngeli.

BONETTA, Gaetano (1996). Insegnare la cultura materiale: Istruzione agraria e lavoro manuale nell'Italia del XIX secolo. Il Risorgimento, (8), 153-63.

Brignoli, Marziano \& Colombo, Arturo (Eds.) (1988). Agostino Depretis e la provincia di Pavia: 1887-1987. Pavia: Torchio de' Ricci.

Caldart, Roseli S. (2000). Pedagogia do Movimento Sem Terra: Escola é mais do que escola. Petrópolis: Vozes.

CALDART, Roseli S. (2004). Elementos para a construção de um projeto político e pedagógico da Educação do Campo. En Mônica C. Molina \& Sônia MEIre SANTos AzEvedo DE JeSus (Eds.), Contribuiçães para a construção de um projeto de Educação do Campo. Brasília, DF: Articulação Nacional "Por uma Educação do Campo".

CALDART, Roseli S. (2009). Educação do campo: Notas para uma análise de percurso. Trabalho, Educação e Saúde, Rio de Faneiro, 7 (1), 35-64.

Caldart, Roseli S., Pereira, Isabel B., Alentejano, Paulo \& Frigotto, Gaudêncio (Eds.) (2012). Dicionário da Educação do Campo. São Paulo: Expressão Popular.

CAмасно, Rodrigo S. (2014). Paradigmas em disputa na educação do campo. 2014. $\mathrm{PhD}$ thesis. São Paulo: Universidade Estadual Paulista.

Carina, Dino (1871). Relazione sul coordinamento delle scuole popolari di arti e mestieri. En Annali del Ministero di Agricoltura, Industria e Commercio 2: 1871 primo trimestre (pp. 65-79). Firenze: Tipografia Claudiana.

CHEMELlo, Adriana (1991). La biblioteca del buon operaio: Romanzi e precetti per il popolo nell'Italia unita. Milano: Unicopli.

Chemello, Adriana (1997). La letteratura popolare e di consumo. En Gabriele Turi et al. (Eds.), Storia dell'editoria nell'Italia contemporanea (pp. 165-92). Firenze: Giunti. Cherubini, Bruno (1977). Carina Dino. En Dizionario biografico degli italiani. Vol. 20. Roma: Istituto dell'Enciclopedia Italiana. 
Corritore, Renzo P. (2012). Storia economica, ambiente e modo di produzione: L'affermazione della gelsibachicoltura nella Lombardia della prima età moderna. Mélanges de l'École française de Rome: Italie et Méditerranée, 124 (1), 291-307.

CoRTi, Paola (1984). Malaria e società contadina nel Mezzogiorno. En Franco Della PeRUTA (Ed.), Annali della Storia d'Italia 7: Malattia e medicina (pp. 632-78). Torino: Einaudi.

Cosmacinı, Giorgio (2016). Storia della medicina e della sanità in Italia: Dalla peste nera ai giorni nostri. Roma/Bari: Laterza.

DE MARCHI, Elena (2009). Dai campi alle filande: Famiglia, matrimonio e lavoro nella " $p$ anura dell'Olona", 1750-1850. Milano: FrancoAngeli.

EsteVES DE OlIVEIRA, Mariana (2014). Saberes necessários à docência nas escolas do campo: As sete dimensões do ensinar e aprender na escola do campo. Boletim GEPEP, Unesp de Presidente Prudente, 03 (05), 27-47

FEDERICO, Giovanni (1997). An Economic History of the Silk Industry, 1830-1930. New York/Cambridge: Cambridge University Press.

Fernandes , Bernardo M. \& Molina, Mônica C. (2004). O campo da Educação do Campo. En Mônica C. Molina \& Sônia Meire Santos Azevedo de Jesus (Eds.), Contribuições para a construção de um projeto de Educação do Campo. Brasília, DF: Articulação Nacional "Por uma Educação do Campo".

FERNANDES, Bernardo M. (2011). Educação do campo e desenvolvimento territorial rural. Revista NERA. Presidente Prudente, (18), 125-35.

Ferrari, Monica \& MAZZARELlo, Paolo (Eds.) (2010). Formare alle professioni: Figure della sanità. Milano: FrancoAngeli.

FonTANA, Giovanni L. (2011). Lo sviluppo economico nell'Europa del xix secolo. En Antonio Di VitTorio et al. (Eds), Dall'espansione allo sviluppo: Una storia economica d'Europa (pp. 265-76). Torino: Giappichelli.

FrasCANI, Paolo (1984). Ospedali, malati e medici dal Risorgimento all'età giolittiana. En Franco Della Peruta (Ed.), Annali della Storia d'Italia 7: Malattia e medicina (pp. 297-331). Torino: Einaudi.

FUMI, Gianpiero (2016). I mungitori nello sviluppo zootecnico della Bassa lombarda nel Novecento. En Monica FerRARI, Gianpiero Fumi \& Matteo Morandi (Eds.), Saperi e professioni della "cascina": Sguardi spazio-temporali (pp. 105-12). Milano: FrancoAngeli.

FumI, Gianpiero \& FAILlA, Osvaldo (Eds.) (2006). Gli agronomi in Lombardia: Dalle cattedre ambulanti ad oggi. Milano: FrancoAngeli.

GeNOvesI, Giovanni (Ed.) (1993). Infanzia in Padania: Condizioni educative e scuola nell'area padana tra '800 e '900. Ferrara: Corso.

GIACCHÈ, Luciano (2012). L'istruzione in agricoltura tra "sapere" e "saper fare". Rivista di Storia dell'Agricoltura, 52 (1), 179-214. 
Hobsbawm , Eric J. (1953). Primitive Rebels: Studies in Archaic Forms of Social Movement in the $19^{\text {th }}$ and $20^{\text {th }}$ Centuries. Manchester: Manchester University Press

Hobsbawm, Eric J. (1964). Labouring Men: Studies in the History of Labour. London: Weidenfeld \& Nicolson.

Hobsbawm, Eric J. (1973). Revolutionaries: Contemporary Essays. London: Weidenfeld \& Nicolson.

Hobsbawm, Eric J. (1998). Uncommon People: Resistance, Rebellion and Fazz. London: Weidenfeld \& Nicolson.

Il censimento della popolazione del Regno d'Italia nella notte del 31 dicembre (1871). Prato: Tip. Giachetti, figlio e C.

LACERDA, Celso L. de \& SANTos, Clarice A. dos (2010). Introdução. En Clarice A. dos Santos, Mônica C. Molina \& Sonia Meire dos Santos Azevedo de Jesus (Eds.), Memória e história do Pronera: Contribuições para a educação do campo no Brasil. Brasília: Ministério do Desenvolvimento Agrário.

MAFFI, Luciano (2012a). Natura docens: Vignaioli e sviluppo economico dell'Oltrepò pavese del XIX secolo. Milano: FrancoAngeli.

MAFFI, Luciano (2012b). Istruzione e sviluppo del capitale umano: L'escursione didattica all'Esposizione di Asti nel 1898 degli alunni della Regia Scuola Pratica di Agricoltura 'Gallini' di Voghera. Bollettino della Società pavese di storia patria, (112), 21136.

MARAZZI, Elisa (2014). Libri per diventare italiani: L'editoria per la scuola a Milano nel secondo Ottocento. Milano: FrancoAngeli.

MAriano, Alessandro (2019). Pedagogia da Resistência e o projeto educativo das escolas do MST. En Fernando Cassio (Ed.), Educação contra a barbárie: Por escolas democráticas e pela liberdade de ensinar. São Paulo: Boitempo.

MAZZOTTI, Omar \& ForNASARI, Massimo (2021). Agricultural education and Italian primary school teachers: the Romagna in the late nineteenth century. Modern Italy, (26), 51-66.

Ministero dell'Istruzione Pubblica (Ed.) (1865). Statistica del Regno d'Italia: Istruzione primaria: Istruzione elementare pubblica per comuni, anno scolastico 186263. Modena: Cappelli.

Ministero dell'Istruzione Pubblica (Ed.) (1866). Statistica del Regno d'Italia: Istruzione pubblica e privata: Istruzione primaria, anno scolastico 1863-64. Firenze:Tofani.

Ministero DELl'IstruZIONe PubBlicA (Ed.) (1878). Relazione statistica sulla istruzione pubblica e privata in Italia, compilata da documenti ufficiali per l'Esposizione di Parigi. Roma: Eredi Botta.

Moioli, Angelo (1981). La gelsibachicoltura nelle campagne lombarde dal Seicento alla prima metà dell'Ottocento. Trento: Libera Università degli Studi di Trento. 
Molina, Mônica (2017). Contribuições das Licenciaturas em Educação do Campo para as políticas de formação de educadores. Educação e Sociedade, 38 (140), 587-609.

Morandini, Maria Cristina (2001). Da Boncompagni a Casati: La costruzione del sistema scolastico nazionale (1848-1861). En Luciano Pazzaglia \& Roberto SANI (Eds.), Scuola e società nell'Italia unita: Dalla legge Casati al Centro-Sinistra (pp. 946). Brescia: La Scuola.

ONGER, Sergio (2010). Verso la modernità: I bresciani e le esposizioni industriali 1800-1915. Milano: FrancoAngeli.

Pagano, Emanuele \& Vigo, Giovanni (2012). Maestri e professori: Profili della professione docente tra Antico Regime e Restaurazione. Milano: Unicopli.

PATRIARCA, Silvana (2010). Italianità: La costruzione del carattere nazionale. Roma/Bari: Laterza.

PazZAgli, Rossano \& Biagioli, Giuliana (Eds.) (2004). Agricoltura come manifattura: Istruzione agraria, professionalizzazione e sviluppo agricolo nell'Ottocento. Firenze: Olschki.

Pazzaglia, Luciano (2002). Scuole e religione nell'Italia giolittiana. Milano: I.S.U. Università Cattolica.

PaZZAGLIA, Luciano \& SANI, Roberto (Eds.) (2001). Scuola e società nell'Italia unita: Dalla legge Casati al centrosinistra. Brescia: La Scuola.

Pellegrino, Anna (2017). Les Fées machines: Les ouvriers italiens aux Expositions universelles (1851-1911). Paris: Classiques Garnier.

PereIRA DE QueIroz, João Batista (2004). Construção das Escolas Famílias Agrícolas no Brasil: Ensino médio e educação profissional. $\mathrm{PhD}$ thesis. Brasília: Universidade de Brasília.

PInI, Paolo (1991). Progresso tecnico e occupazione: Analisi economica degli effetti di compensazione agli inizi dell'Ottocento. Bologna: Il Mulino.

PODESTÀ, Ernesto (1876). Trattato elementare di agricoltura: Con guida all'insegnamento agrario compilata da Giuseppe Pasotti. Voghera: Giuseppe Gatti.

ProsPeri, Adriano (2019). Un volgo disperso: Contadini d'Italia nell'Ottocento. Torino: Einaudi.

Romani, Mario (1957). L'agricoltura in Lombardia dal periodo delle riforme al 1859: Struttura, organizzazione sociale e tecnica. Milano: Vita e Pensiero.

Romani, Mario (1963). Un secolo di vita agricola in Lombardia (1861-1961). Milano: Giuffrè.

SAGLIO, Pietro (1881). Monografia agraria del Circondario diVoghera. Stradella: G. Perea. SAltini, Antonio (2006). Istituzioni agrarie e progresso nelle campagne: Nasce a Piacenza il moto di rinnovamento nazionale. Roma: Spazio Rurale.

SAsso, Gennaro (1985). Tramonto di un mito: L'idea di "progresso" tra Ottocento e Novecento. Bologna: Il Mulino. 
ScotT, James C. (1985). Weapons of the Weak: Everyday Forms of Peasant Resistance. New Haven:Yale University Press.

SILVA, Eduardo (1989). A função ideológica da brecha camponesa. En João J. REIS \& Eduardo SILva (Eds.), Negociação e conflito: a resistência negra no Brasil escravista. São Paulo: Companhia das Letras.

SOCIETÀ DEGLI AGRICOLTORI ITALIANI (Ed.) (1901). L'Italia agricola alla fine del secolo XIX: Trentacinque monografie inviate alla Societé des agriculteurs de France nell'occasione della Esposizione universale di Parigi del 1900. Roma: Unione Cooperativa.

SolDANI, Simonetta (1981). L'istruzione tecnica nell'Italia liberale (1861-1900). Studi storici, (1), 79-117.

Thompson, Edward P. (1967). Time, Work Discipline and Industrial Capitalism. Past and Present, (38), 56-97.

VAQUeRo PIÑEIRO, Manuel (2006).'Empirici' e 'istruiti': Fattori e periti agrari in Italia tra XIX e XX secolo. En Gianpiero FUMI \& Osvaldo FaILla (Eds.), Gli agronomi in Lombardia: Dalle cattedre ambulanti ad oggi (pp. 84-104). Milano: FrancoAngeli.

VAQUero PIÑEIRO, Manuel (2011). Da fattori a periti agrari: Formazione professionale e modernizzazione dell'agricoltura in Umbria (1884-1929). Foligno: Editoriale umbra.

VAQUero PIÑEIRO, Manuel (2012). Edda Bellucci (1884-1905): Primo direttore della Regia Scuola Patrica d'Agricoltura di Todi. Rivista di storia dell'agricoltura, (1), 139-61.

VAQUERo PIÑEIRo, Manuel (2014). Insegnare, disciplinare e governare l'agricoltura. En Mario Tosti (Ed.), Storia dell'Umbria dall'unità a oggi: Uomini e risorse (pp. 151-80). Venezia: Marsilio.

VASTA, Michelangelo (1999). Innovazione tecnologica e capitale umano in Italia (18801914): Le traiettorie della seconda rivoluzione industriale. Bologna: Il Mulino.

VIGO, Giovanni (1971). Istruzione e sviluppo economico in Italia nel secolo XIX. Torino: ILTE.

VIgo, Giovanni (2012). Il maestro elementare. En Emanuele Pagano \& Giovanni Vigo (Eds.), Maestri e professori: Profili della professione docente tra Antico Regime e Restaurazione (pp. 11-124). Milano: Unicopli.

VIGo, Giovanni (2017). Il vero sovrano dell'Italia: L'istruzione degli adulti nell'Italia dell'Ottocento. Bologna: Il Mulino.

ZAMPA, Raffaello (1881). La demografia italiana studiata più specialmente in riguardo all'azione dei monti e delle pianure sulla vita dell'uomo. Bologna: Zanichelli.

ZANINELli, Sergio (Ed.) (1991). Le conoscenze agrarie e la loro diffusione in Italia nell'Ottocento. Torino: Giappichelli. 